\title{
MCT によるオーストリア及びドイツの学生の空間認識力の分析
}

\author{
堤 江美子 \\ 大妻女子大学社会情報学部
}

要旨 : 図法幾何学教育のシステムが大きく異なるオーストリア、ドイッの大学生を対象に、図学教育と空間 認識力育成効果との関連を詳しく調べる目的で空間認識力テスト（MCT）を実施した。その結果、図法幾何学 教育で育成された能力と空間認識力の向上の関連性が確認された。また、眓法幾何学によって、直感的な 3 次元形状のイメージ生成能力とともに形状を論理的に理解する能力も向上したことが推測された。さらに解 答選択肢選択率の分析から、図法幾何学教育によって育成される能力の内容を分析する可能性が得られた。 キーワード : 空間認識力、切断面実形視テスト、オーストリア、ドイッ

\section{1.はじめに}

図学教育の分野では、知識および技術に関する習 得内容の議論にともなって、3 次元的図形処理能力 の育成問題が注目されるようになり、近年、2 次元 で示された眓から３次元立体を認識する際に、図学 で教育される知識や技術がどのように関与している のか調べるためにさまざまなテストが行われている。 このようなテストの一つとして切断面実形視テスト

(Mental Cutting Test : 以下 MCT と略す) がある。 MCT は、もともと米国で大学入学資格試験に用いら れていたテスト $\left(\mathrm{CEEB}^{1)}\right.$ ，1939) の一部を、鈴木ら ${ }^{2)}$ （1990）が、学生の空間認識能力を評価する尺度の 一つとして位置づけたものである。

MCT は、立体とこれを切断する切断面を透視図で 与え、切断された立体の切り口の実形を 5 つの選択 肢から選んで解答させるもので、 25 題の問題からな っている。今日まで、さまざまな被験者を対象とし たデータが蓄積されつつあり、MCT 得点の平均值を 統計的に分析するだけでなく、MCT が空間認識力の どのような側面を評価しているのかについても明確 にしようとする研究が進みつつある。現在のところ、 MCT は主として、「2 次元の図から 3 次元立体のイメ ージを生成する能力」を反映しているものとされて いる (Saito, et al. ${ }^{3)}(1996)$ )。

鈴木 ${ }^{4)}$ (2000)は MCT を評価基準とする図学教育に よる空間認識力の育成効果について、図法幾何学教 育あるいは図学関連教育における授業の前・後テス トの結果及び対照群のテスト結果から、MCT により 評価される空間認識力が図法幾何学教育によって向
上することが示された、と述べている。

鈴木はさらに、空間認識力の育成に寄与する要因 として、空間認識力の育成効果が、図法幾何学 $>$ 機 械製図、EG（手描き）> EG（CAD）の順に大きい傾向 にあったことを述べ、“図法幾何学”及び“手描き” が空間認識力の育成にとって重要であることを指摘 している。

そこで図学教育と空間認識力の育成効果との関連 を詳しく調べるために、教育システム全般が日本と 異なり、また、より幾何学的色彩を帯びた眓法幾何 学教育を行っているオーストリア及びドイツにおい て、大学生を対象に図学教育の前後で MCT を実施し た。

\section{2. オーストリアの図学教育}

オーストリアでは図 1 に示すように国が教育課程 の基準を定める義務教育課程は 6 歳から 15 歳までの 9 年間である。初等教育は、はじめの 4 年間の小学 校で行われる。その後の中等教育は、一般中等学校 (AHS Unterstufe) と中学校 (Hauptschule) の 2 種類に分かれる。それぞれ 4 年間であるが、どちら に進学するかは、成績と適性によって決められる。 主として高等教育機関に進むものが一般中等学校へ、 義務教育後すぐに就職するか職業学校へ進むものが 中学校へと進む。

14 歳からは、大きく分けて、 4 年制の一般高等学 校(AHS Oberstufe)、 5 年制の職業教育高等学校(BHS)、 高等技術学校 (HTL; これは職業教育高等学校の 1 種 で高等工業専門学校)、1 年制の職業教育学校 (PTS) 
などがあり、最初の 1 年目で義務教育は終了する。 この一般高等学校はシステムとしては一般中等学校 から継続して 8 年教育 (AHS) となっており、それぞ れ下級 AHS、上級 AHS と呼称されている。

高等学校の最終学年には卒業検定試験があり、こ れに受かったものには大学入学資格 (Mature) が与 えられる。

大学は国立の総合大学・工科大学・単科大学合わ せて13 (2004年) 校と芸術大学6校、及び私立の単科 大学がある。一部、芸術系大学のように芸術的才能 に関する入学選抜が行われる大学もあるが、通常、 大学入学資格を持つものは希望する大学へ進学でき る。進学率は $10 \%$ 程度である(全人口は約 800 万人)。 大学の修業年限は 4 年から 5 年半で専攻によって異な る。

\section{3. 図法幾何学教育}

\section{1 大学入学以前}

図学教育は中等教育から始まる。内容は大別して 「幾何作図」(英名 : Elementary geometry) と「図 法幾何学」に分かれる。受講率は $50 \%$ 程度である。 「幾何作図」は一般中等学校及び中学校で高学年 $(13$ 〜14 歳)になって学習する。内容は Geometrical Drawing 及び Computer Drawing である（附表 1 )。 一方、「四法幾何学」は一般高等学校、職業教育高等 学校の高学年（前者では 17〜18 歳、後者では 15〜 16 歳)で学ぶ。内容はより理論的で授業中に手描き で図を描くことは通常ない（附表 2 )。

\section{2 大学入学後}

中等教育での「幾何作図」及び「図法幾何学」未 習の学生のために、大学では図学の補習コース（2 時間 $\times 2$ 日/週、半期) を行っている（ウイーンエ 科大学の場合)。この補習コースにおいては中等教育 の教科書などを使って講義を行う。

\section{3 教職課程「幾何学」}

先に述べたように中等教育から図法幾何学の授業 が始まるため、眓法幾何学教員養成のための教職課 程が大学にはある（附表 3 )。

\section{MCT の実施}

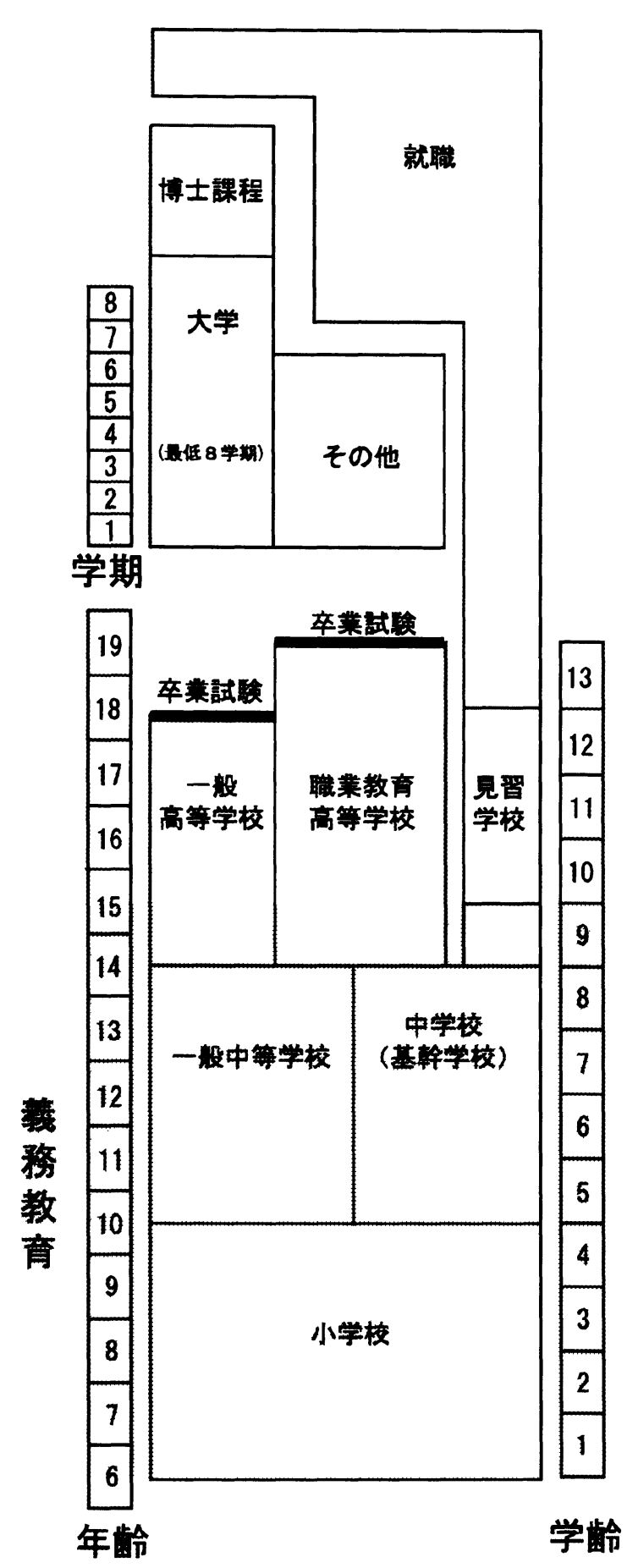

図 1 オーストリアの教育システム

表 1 のような 5 つの被験者群を対象として、半期の 図法幾何学授業の開始直後と最終授業日とに 2 回、 MCT を実施した。名称に 'dg'が付く被験者群は図 法幾何学のクラス、'exp'が付く群は既に図法幾何 学を終えているクラスである。なお、参照群として 実施したUAK_ref は広告デザインのクラスで授業の 中で図法幾何学は教えない。 


\begin{tabular}{|c|c|c|}
\hline 被験者群 & 大学 & MCT 前テスト実施時の図学経験 \\
\hline TUW_dg_exp & ウイーン工科大学 ·図法幾何学教職コース & 図学既習 \\
\hline TUW_dg & ウイーン工科大学・全般 & 図学未習（補習） \\
\hline UAK_dg_exp & ウイーン応用美術大学 & 図学既習 \\
\hline UAK_dg & ウイーン応用美術大学 & 図学末習 \\
\hline UAK_ref & ウイーン応用美術大学 & 図学なし \\
\hline TUD_dg & ドレスデンエ科大学 & 図学末習 \\
\hline
\end{tabular}

\section{5. 前テストの結果}

表 2 に授業初日に行った MCT 前テストの結果から 各群の平均得点を示す。四法幾何学既習の 2 群では、 未習群に対して有意にテストの得点が高く、テスト 以前に図法幾何学を学習したか否かで MCT で測られ る空間認識力に差があることが分かった。また、男 女間ではほほ全てのグループにおいて男子で有意に 得点が高かった。オーストリア及びドイッでは日本 と教育システムが大きく異なるうえ、このデー夕は 横断的データではあるが、以上の結果から図法幾何

表 2 MCT の平均得点

\begin{tabular}{|c|c|c|c|c|}
\hline 被医者群 & 性別 & 平均值 & 性差 & 検定(※) \\
\hline \multirow{3}{*}{ TUW_dg_exp } & 全員 & .18 .57 & & \\
\hline & 女子 & 15.57 & \multirow{2}{*}{$5.25 * *$} & \\
\hline & 男子 & 20.92 & & \\
\hline \multirow{3}{*}{ UAK_dg_exp } & 全員 & 18.29 & & 0.38 \\
\hline & 女子 & 17.11 & \multirow{2}{*}{1.40} & \\
\hline & 男子 & 19.17 & & \\
\hline \multirow{3}{*}{ TUW_dg } & 全員 & 15.28 & & $3.39 * *$ \\
\hline & 女子 & 13.76 & \multirow{2}{*}{$2.87 * *$} & \\
\hline & 男子 & 16.63 & & \\
\hline \multirow{3}{*}{ UAK_dg } & 全員 & 14.48 & & $4.19 * *$ \\
\hline & 女子 & 13.28 & \multirow{2}{*}{$\begin{array}{l}4.05 \\
(p=0.08)\end{array}$} & \\
\hline & 男子 & 17.33 & & \\
\hline \multirow{3}{*}{ TUD_dg } & 全員 & 15.39 & & $2.77 * *$ \\
\hline & 女子 & 13.98 & \multirow{2}{*}{$3.79 * *$} & \\
\hline & 男子 & 17.77 & & \\
\hline
\end{tabular}

※ 検定は、TUW_dg_exp 全員と他の各群全員との得点差の 有意差㭘定結果 $\quad(* * \mathrm{P}<1 \%)$
学と空間認識力の育成効果、および MCT によって測 られる空間認識力の性差に関しては、概ね日本と同 様の傾向が見られることが分かった。

\section{6. 前後テストの比較結果}

\section{1 平均得点}

表 3 に各群の前テスト及び学期の最後に行った後 テストの平均得点を示す。参照群以外では、後テス トで前テストに対して平均得点が 1.6 から 3.4 点増 加した。

図法幾何学の授業を通して、MCT で測られる空間 認識力は既習群のそれに近づいているはずであると の予測から、もともと図法幾何学を学習している TUW_dg_exp 群の前テストの平均得点を基準とし、図 法幾何学を学期中に履修した他の 3 つの未習群及び 参照群の後テストの平均得点と比較した。比較の結 果、両者の平均得点間にほぼ有意差は見られず、空 間認識力の向上に関して図法幾何学授業で育成され た能力と一定の関係があることが確認された。

表 3 MCT の前後テストの平均得点の比較

\begin{tabular}{|l|c|l|c|}
\hline \multicolumn{1}{|c|}{ 被匰者群 } & 前テスト & 後テスト & 得点上昇 \\
\hline TUW_dg_exp & 20.0 & 21.9 & 1.9 \\
\hline TUW_dg & 15.4 & 18.8 & 3.4 \\
\hline UAK_dg & 14.4 & $16.8 *$ & 2.4 \\
\hline TUD_dg & 16.8 & 18.4 & 1.6 \\
\hline UAK_ref & 12.7 & $12.7 * *$ & 0.0 \\
\hline
\end{tabular}

- $\mathrm{t}$ 検定は TUW_dg_expの前テストと他の後テストの差 (* $\mathrm{P}<5 \%, * * \mathrm{P}<1 \%)$ 


\section{2 問題ごとの正解率}

図 2 は、問題毎の正解率を被験者群ごとにグラフ に示したものである。上段が前テストの正解率、下 段が後テストの正解率である。この 2 つの゙ラフは、 網点の面グラフで示された図法幾何学既習群の前テ ストの正解率の大きい順に並べられている。

図 2 の上段のグラフから、図法幾何学末習群（棒 グラフ 2 群及び線グラフ 1 群）は、図学履修前では 既習群（網点の面グラフ）に比べて問題毎の正解率 の様相が大きく異なることが分かる。とくに、線グ ラフで表された美術系図法幾何学末習群 (UAK_dg_Pre) では、極端に正解率の低い問題が見 られる。

一方、図学履修後のグラフ（下段）から、図法幾 何学を履修したことによって、正解率の向上が見ら れる。

図 3 は TUW_dg_exp の前テストの正解率順に並べ た各問題の未習群の平均上昇率((後テスト正解率一 前テスト正解率)/後テストの正解率 $\times 100)$ である。 この図から、特に既習群にとっても難しい問題（問 題番号 $17,19,22,10,21,25,9$ など）に未習群で正解 率の向上が読み取れる。これに対して、もとより正 解率のある程度高かった問題では、さほど極端な正 解率の向上は見られなかった。

図 4 は図 3 の問題をパターン判別問題と量判別問 題とに分けて示したものである。パターン判別問題 及び量判別問題の全平均上昇率はそれぞれ、 $13.0 \%$ 、 13.4\%であった。パターン判別問題と同様に、あるい はそれ以上に、解答に論理的思考を必要とするとさ れている量判別問題においても図学教育の後で正解 率の上昇がみられたことから、図法幾何学を履修し たことによって、直感的に 3 次元形状をイメージし て把握する能力とともに、形状を論理的に理解する 能力も向上したことが推測された。

\section{4 既習群·未習群の解答選択肢}

図 5 は図法幾何学既習群 (exp) と未習群 (non) で解答傾向に差が見られた問題の解答選択肢ごとの 選択率である。この図から、これらの問題では困法 幾何学教育によって正解が容易に増加することが推
前テスト

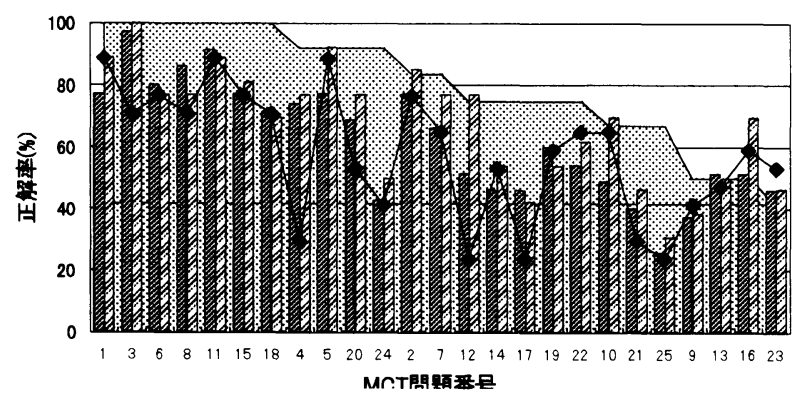

後テスト

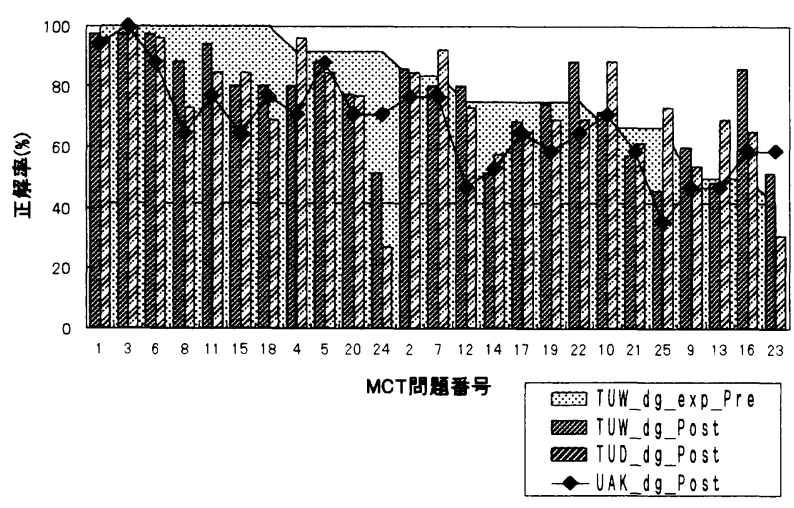

図 2 問題ごとの正解率

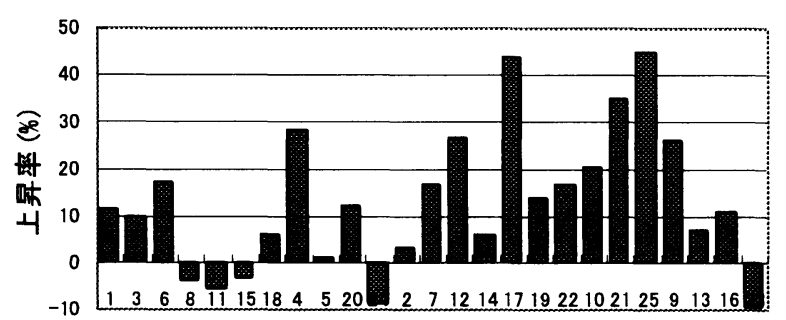

問題番号

図3 問題ごとの平均上昇率 (TUW_dg_exp の正解率順) 上昇率 $=($ 後テストー前テスト $) /$ 後テスト $\times 100$

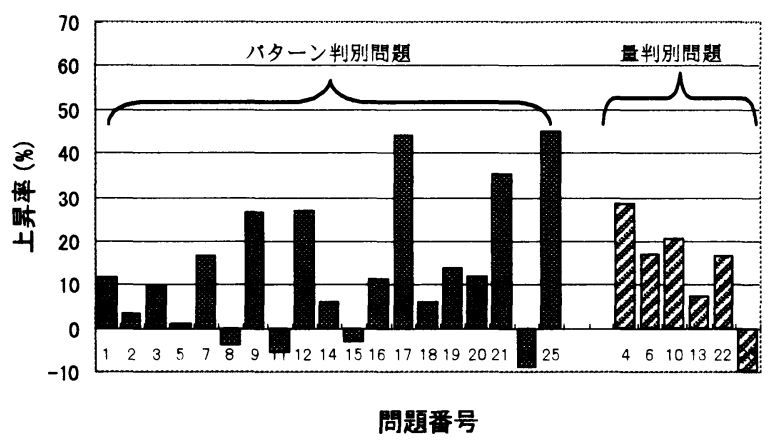

図4 パターン判別/量判別問題の平均上昇率 
測できる。右の問題の立体は 2 つの軸方向が 90 度異 なる円柱の積集合であり、形状的には見慣れないも のである。しかし、幾何学的な知識をもとにこの立 体を見れば、より 3 次元的に理解できる問題でもあ る。

図 6 は図法幾何学既習群 (exp) と未習群 (non) で解答傾向にあまり差が見られなかった問題の解答 選択肢選択率である。左の立体では、部分的な特徵 をつかめば解答は 1 つに定まるため、立体を 3 次元 的にうまくイメージできなくても正解に至る確率は 高い。一方、右の問題は、立体と切断面との相対的 な位置関係の把握が難しい問題で、このような問題 では図法幾何学の履修の有無を問わず解答が難しか ったことが分かる。

これより、解答選択肢選択率を詳細に分析するこ とによって、授業の中で育成された能力の詳細を調 べることができると考えられた。
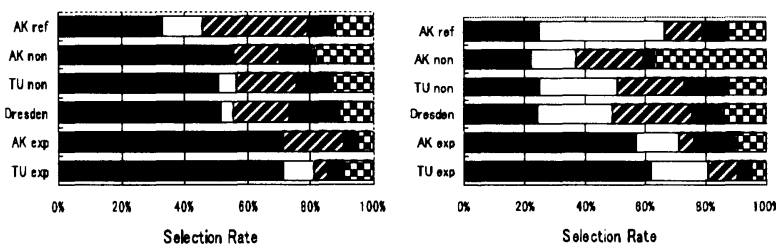

$\square 4 \square 3 \square 1 \square 2 \square 5$ Unsolved

घ $\square 4 \square 2 \square 5 \square 1 \quad$ Unsolved 19 B

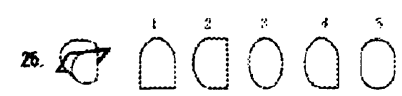

図 5 既習群と末習群で差の見られた解答選护.肢 選択率をもつ問題

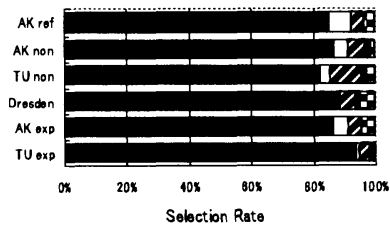

$\square 5 \square 1 \square 3 \square 2 \square 4$ QUnsolved

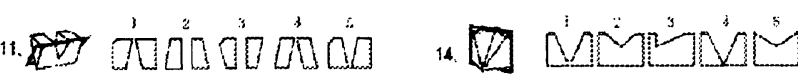

図 6 既習群と未習群で差の見られなかった解答 選択肢選択率をもつ問題

\section{7. おわりに}

四法幾何学に関する教育システムが大きく異なる オーストリア、ドイツの大学生を対象に、図法幾何 学の学習とMCT の得点の変化を調べた。その結果、

1)MCT 実施以前に図法幾何学を履修してきた学生で は、履修していない学生に比べて MCT 得点は有意に 高かった。

2)既習群及び未習群の前・後テストの結果から、図 法幾何学教育で育成された能力と空間認識力の向上 の関連性が確認された。

3)図法幾何学を履修したことによって、直感的に 3 次元形状をイメージして把握する能力とともに、形 状を論理的に理解する能力も向上したことが推測さ れた。

4)既習群と末習群の解答選択肢選択率の傾向から、 四法幾何学教育の中でどのような能力が育成された かを知る手がかりを得ることができた。

今後、解答選択肢の選択率と図法幾何学のカリキ ユラム及び教育方法との関連性の詳細な調査を通し て分析を進めたい。

\section{参考文献}

1) CEEB Special Aptitude Test in Spatial Relations, Developed by College Entrance Examination Board, U.S.A. (1939).

2）鈴木賢次郎、脇田早紀子、永野三郎:図学教育に おける直感的 2-3 次元図形処理能力の育成効果. 図 学研究, 49 号, pp.21-28(1990).

3) T.Saito, Ku.Shiina, K.Suzuki and T.Jingu: Spatial Ability Evaluated by a Mental Cutting Test. Proc. 7th ICECGDG, Cracow, Poland, pp.569-573(1996).

4）鈴木賢次郎 : 図学関連教育による空間認識力の育 成一MCT による調査研究を基に一. 日本図学会 2000 年度大会講演論文集, pp.21-26(2000). 
附表 $1 「$ 幾何作図」のカリキュラム例

\begin{tabular}{|l|l|}
\hline \multicolumn{2}{|c|}{ 立体の軸測投象的表現 } \\
\hline & 軸測投象的表現 \\
\hline & 正面軸測投象（斜投象） \\
\hline & 水平投象 \\
\hline & 面の可視・不可視 (隱線、隱面消去) \\
\hline & デルト座標系 \\
\hline & モデリングプロセス・分解立体図 \\
\hline & 展開 \\
\hline & 平面による切断 \\
\hline 複面投影 \\
\hline & 平面・正面・側面図の作図と読み取り \\
\hline & 副面図 : 表現方法と作図補助としての副面図 \\
\hline & 縮尺記入 \\
\hline & 工業製図（製造のための作図） \\
\hline 幾何学的基本作図 \\
\hline & 実長、実形 \\
\hline 曲面 \\
\hline & \multicolumn{2}{|l|}{ スケッチによる表現 } \\
\hline & 特別な曲面 : 円柱、円錐 \\
\hline & 展開 \\
\hline & モデリングプロセス \\
\hline 円錐曲線 \\
\hline & 楕円 \\
\hline & 放物線、双曲線 \\
\hline
\end{tabular}

附表 2 一般高等学校の必修科目「図法幾何学」の 学習目標

\section{専門に関する目標}

幾何学的形状、構造の把握、解析及び言語 による記述

空間的問題を作図によって解く

幾何学的概念の正確な理解

三次元立体のフリーハンド・スケッチ

立体の測定と設計図の作成

適切な投影法による三次元立体の作図表現 立体の作図的表現を読む

作図技術の熟達

学際的な目標

空間認識（三次元空間でを考える）

コミュニケーション手段としての作図利用

丁寧で正確な作業、論理的思考、正確な言 語による表現

数学、情報処理、自然科学、工学及び造形 芸術への横のつながりの認識

図的表現力の学習
附表 3 図法幾何学教職課程の講義一覧

\begin{tabular}{|c|c|}
\hline 期 & 名称 \\
\hline \multirow[t]{11}{*}{1 期 } & 図法幾何学 0 \\
\hline & 図法幾何学 1,2 \\
\hline & 図法幾何学 $1 \mathrm{a}, 1 \mathrm{~b}, 2 \mathrm{a}, 2 \mathrm{~b}$ \\
\hline & 運動学 \\
\hline & 射影幾何学 $1,2,3$ \\
\hline & 曲線・曲面の解析幾何学 \\
\hline & 教職のための CAD \\
\hline & 教職訓練 \\
\hline & 教職研究 \\
\hline & 幾何作図（G Z）教職 \\
\hline & 初歩的な幾何学 \\
\hline \multirow[t]{22}{*}{2 期 } & 写像 1,2 \\
\hline & 非ユークリッド幾何 \\
\hline & 微分幾何 1,2 \\
\hline & Konstruktive 微分幾何 \\
\hline & 工学における幾何学 \\
\hline & Computer Aided Geomtric Design \\
\hline & セミナー \\
\hline & 幾何学実習 \\
\hline & AHS 教授法 \\
\hline & BHS 教授法 \\
\hline & 図法幾何学授業におけるニューメディア \\
\hline & Algorithmische Geometrie * \\
\hline & Computer Aided Geometric Design $*$ \\
\hline & Hohere 運動学 * \\
\hline & 選択 : 線形幾何学 $* *$ \\
\hline & 選択 : 円と球の幾何学 $* *$ \\
\hline & 選択 : 非ユークリッド幾何学 ** \\
\hline & 選択 : 幾何学的トポロジー *** \\
\hline & 選択 : 離散幾何学 $* *$ \\
\hline & 選択 : 空間認識テスト \\
\hline & 選択 : インターネット上での幾何学的表現 \\
\hline & 他 \\
\hline
\end{tabular}

* 応用幾何学とコンピュータ指向幾何学

$* *$ 高等幾何学

1 期 : 入学後 4 学期 $(2$ 年間)

2 期 : その後 $4 \sim 5$ 学期（2 年間〜2.5 年間） 